\title{
Comparison of Different Methodologies for DNA Extraction from Aegla longirostri
}

\author{
João Vitor Trindade Bitencourt, Paula Angélica Roratto, Marlise Ladvocat Bartholomei- \\ Santos* and Sandro Santos \\ Curso de Pós-Graduação em Biodiversidade Animal; Centro de Ciências Naturais e Exatas; Universidade Federal \\ de Santa Maria - UFSM; Faixa de Camobi, Km 9; 97105-900; marlise@smail.ufsm.br; Santa Maria - RS - Brasil
}

\begin{abstract}
The aim of this study was to compare some DNA extraction methodologies for Aegla longirostri. The protocols were based on the traditional phenol-chloroform DNA extraction methodology and using a commercial kit for DNA extraction. They differed in tissues used, the addition - or not - of $\beta$-mercaptoethanol to the lysis buffer, times and methods for the animal's conservation (frozen, in ethanol or fresh). Individuals stored at $-20^{\circ} \mathrm{C}$ for a long time supplied lower molecular weight DNA than those stored for a short time. The best yield for the specimens preserved in ethanol was obtained for 15 days storage in 95\% ethanol. The kit resulted in a low quantity of high molecular weight DNA. The best protocol for DNA extraction from Aeglidae, and probably for other crustaceans should, therefore, utilize fresh specimens, with addition of $\beta$-mercaptoethanol to the lysis buffer.
\end{abstract}

Key words: Anomura, Aeglidae, freshwater crab, DNA extraction

\section{INTRODUCTION}

The Aeglidae are a distinct family of decapod crustaceans because they are the single freshwater group of the Anomura. Presently, the genus Aegla consists of approximately 60 known species and subspecies, which are endemic of the subtropical and temperate regions of South America (BondBuckup and Buckup, 1994).

Several astonishing features of this group have called attention from researchers regarding its systematic, morphology, ecology and biogeographycal aspects. Some aeglids have restricted distribuition, whilst others are widespread, such as populations of Aegla longirostri that dwell in central and east regions of Rio Grande do Sul state - Brazil (Bond-Buckup, 2003). These populations have settled in distinct hydrographic nets, separated by a watershed that was formed at about eleven millions years ago (Moreira and Lima, 1977).

Molecular biology offers useful tools for the population and phylogenetic studies, which have been widely applied in taxonomic and conservation researches for several crustacean orders (Ovenden et al., 1992; Staton and Felder, 1995; Levinton et al., 1996; Chu et al., 1999; Schubart et al., 2000; Xu et al., 2001; Fratini and Vannini, 2002). Despite its importance and particularities, there are few molecular studies with the genus Aegla (D'Amato and Corach, 1997; Perez-Lozada et al., 2002a; Perez-Lozada et al., 2002b). Most approaches require primarily high molecular weight DNA, which demands undegraded material with an efficient DNA extraction method.

\footnotetext{
${ }^{*}$ Author for correspondence
} 
The objective of the preset work was to compare several protocols for DNA extraction and purification from A. longirostri, using different conditions of lysis, tissues, the phenol-chloroform method and the QIAamp DNA Mini Kit (QIAGEN), in order to determine the best conditions for specimens maintenance.

\section{MATERIALS AND METHODS}

\section{Individual collections and storage}

Specimens of $A$. longirostri were transported from the collection place in individual bags filled with water and stored at $-20^{\circ} \mathrm{C}$, in ethanol or alive in an aquarium, until the laboratory experiments were performed.

\section{DNA extraction}

Prior to dissection, live individuals were sacrificed at $-20^{\circ} \mathrm{C}$ during $30 \mathrm{~min}$. All the samples had $\sim 80$ $\mathrm{mg}$ of their tissues removed under a cold surface and, except the ones submitted to QIAamp DNA Mini Kit, incubated in $400 \mu \mathrm{L}$ digestion buffer (100 mM Tris- $\mathrm{HCl}$ (pH 8.0); 100 mM EDTA (pH 8.0); $250 \mathrm{mM} \mathrm{NaCl} ; 2 \%$ SDS and $800 \mu \mathrm{g}$ proteinase $\mathrm{K}$ ) at $56^{\circ} \mathrm{C}$ for $4 \mathrm{~h}$.

After incubation, DNA was extracted according to the phenol-chloroform method (Sambrook and Russel, 2001). RNA was removed from all the samples by the addition of $0.1 \mu \mathrm{g} / \mu \mathrm{L}$ RNAse A and incubation for $2 \mathrm{~h}$ at $37^{\circ} \mathrm{C}$. A further purification step was performed using 13\%PEG $8000 / 1.6 \mathrm{M}$ $\mathrm{NaCl}$, followed by two washes in $70 \%$ ethanol (Sambrok and Russel, 2001).

Fourteen specific procedures were tested, which differed regarding their storage time and condition (fresh, iced or in ethanol), addition of $\beta$ mercaptoethanol in lysis buffer and tissues used (gills, hepatopancreas and muscles; see Table 1). Protocol K was accomplished with QIAamp DNA Mini Kit, according to the manufacturer's instruction (QIAGEN).

Table 1 - Tested protocols of DNA extraction from A. longirostri. All methods were accomplished with the same lysis and phenol-chloroform extraction procedures.

\begin{tabular}{|c|c|c|c|c|}
\hline \multirow{2}{*}{ Protocol } & \multirow{2}{*}{ Tissue* } & \multirow{2}{*}{$\begin{array}{c}\text { Addition of } \\
\beta \text {-mercaptoethanol }\end{array}$} & \multicolumn{2}{|r|}{ Storage } \\
\hline & & & Time & Method \\
\hline $\mathrm{A}$ & $\mathrm{M}, \mathrm{G}$ and $\mathrm{H}$ & No & $30 \mathrm{~min}$ & $-20^{\circ} \mathrm{C}$ \\
\hline$A^{\prime}$ & $\mathrm{M}, \mathrm{G}$ and $\mathrm{H}$ & No & 15 days & $-20^{\circ} \mathrm{C}$ \\
\hline $\mathrm{B}$ & $\mathrm{M}$ and $\mathrm{G}$ & No & 15 days & $-20^{\circ} \mathrm{C}$ \\
\hline $\mathrm{B}^{\prime}$ & $\mathrm{H}$ & No & 15 days & $-20^{\circ} \mathrm{C}$ \\
\hline $\mathrm{C}$ & $\mathrm{M}$ and $\mathrm{G}$ & No & $30 \mathrm{~min}$ & $-20^{\circ} \mathrm{C}$ \\
\hline $\mathrm{D}$ & $M$ and $G$ & Yes & $30 \mathrm{~min}$ & $-20^{\circ} \mathrm{C}$ \\
\hline $\mathrm{E}$ & $M$ and $G$ & Yes & 45 days & $-20^{\circ} \mathrm{C}$ \\
\hline $\mathrm{F}$ & $\mathrm{M}$ and $\mathrm{G}$ & Yes & 4,5 years & $70 \%$ ethanol room temp. \\
\hline$F^{\prime}$ & $\mathrm{M}$ and $\mathrm{G}$ & No & 4,5 years & $70 \%$ ethanol room temp. \\
\hline $\mathrm{G}$ & $M$ and $G$ & No & 3 days & $70 \%$ ethanol room temp. \\
\hline $\mathrm{H}$ & $\mathrm{M}$ and $\mathrm{G}$ & No & 3 days & $70 \%$ ethanol $-20^{\circ} \mathrm{C}$ \\
\hline $\mathrm{I}$ & $\mathrm{M}$ and $\mathrm{G}$ & Yes & 15 days & $80 \%$ ethanol room temp. \\
\hline $\mathrm{J}$ & $\mathrm{M}$ and $\mathrm{G}$ & Yes & 15 days & $95 \%$ ethanol room temp. \\
\hline $\mathrm{K}$ & $M$ and $G$ & $* *$ & $30 \mathrm{~min}$ & $-20^{\circ} \mathrm{C}$ \\
\hline
\end{tabular}

* Abbreviations: M, muscles; G, gills and $\mathrm{H}$, hepatopancreas. ** Solutions from the kit with unknown composition

\section{DNA quality determination}

The DNA quality was accessed by two ways: molecular weight and suitability for downstream application in PCR (Polymerase Chain Reaction). The molecular weight of the DNA yielded by each method was determined by electrophoresing a 5 $\mu \mathrm{L}$ sample in a $0.8 \%$ TBE-agarose gel, stained with ethidium bromide (Fig. 1-3). To further demonstrate the quality of the extracted DNA, all the samples were submitted to a PCR to amplify a nearly 150bp fragment of the CO1 (Cytochrome oxidase I) gene. Reaction volume was $25 \mu \mathrm{L}$ with $200 \mathrm{ng}$ of extracted DNA (except for protocols that yielded no detectable DNA), $0.1 \mathrm{mM}$ of each dNTP, 1.25 U Taq polymerase (Cenbiot), 1X Taq buffer and $1.5 \mathrm{mM} \mathrm{MgCl}$, both supplied with the enzyme, and 20 pmol of each primer: $\mathrm{CO} 1$ forward 5'ATGTACATATCGCCCGTCGC3' and 
$\mathrm{CO} 1$ 5'CGATTATGCTACCTTTGCAC3'. Primers were designed by conserved regions alignment of several mitochondrial DNA sequences from Crustaceans deposited in Genbank. The PCR parameters were $5 \mathrm{~min}$ initial denaturation at $94^{\circ} \mathrm{C}$ followed by 30 cycles of $1 \mathrm{~min}$ denaturation at $94^{\circ} \mathrm{C}, 45 \mathrm{sec}$ annealing at $55^{\circ} \mathrm{C}$, and $1 \mathrm{~min}$ extension at $72^{\circ} \mathrm{C}$, finishing with 7 min extension at $72^{\circ} \mathrm{C}$. PCR products were electrophoresed in $6 \%$ Polyacrylamide gel for $90 \mathrm{~min}$ and silver stained (Sambrook and Russel, 2001).

\section{RESULTS}

Except Protocols F/F' and $\mathrm{H}$ that were performed with individuals conserved for 4.5 years and for 3 days in $70 \%$ ethanol respectively, all the other protocols yielded DNA of different molecular weights visible on agarose gel under UV light. Protocols C, D, E and $\mathrm{K}$ yielded high molecular weight DNA. Protocols A, A', B, I and J produced both high molecular weight and degraded DNA. Protocols B' and G yielded only degraded DNA. Protocols F, F' and $\mathrm{H}$ yielded non-detectable DNA on agarose gel stained with ethidium bromide under UV light. Protocols A, A', B, and B', which lacked $\beta$-mercaptoethanol in the lysis buffer, produced lower molecular weight DNA, and degradation was intensified with the increasing of storage time (Fig. 1).

Comparison among tissues indicated that muscle and gills were more suitable for DNA extraction than samples containing hepatopancreas (lane B': Fig. 1).

Protocols that included $\beta$-mercaptoethanol in lysis buffer provided higher molecular weight DNA, mainly if samples were sacrificed $30 \mathrm{~min}$ before the dissection by freezing - protocol D (lane D: Fig. 2). Ice stored individuals for a long time presented less degraded DNA by adding $\beta$ mercaptoethanol - protocol E (lane E: Fig. 2).

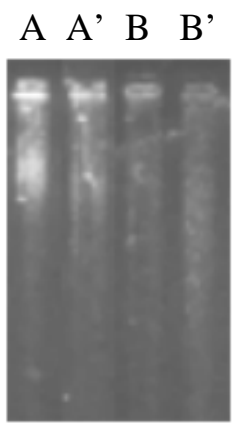

Figure 1 - Electrophoresis in $0.8 \%$ agarose gel of extracted DNA samples. Letters correspond to the protocols A, A', B and B'

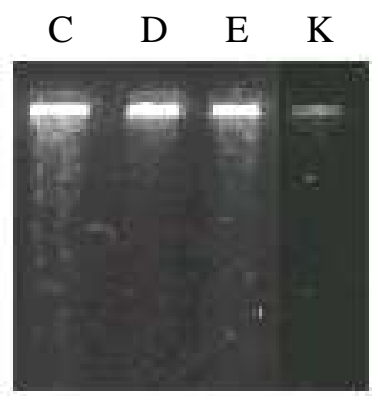

Figure 2 - Electrophoresis in $0.8 \%$ agarose gel of extracted DNA samples. Letters correspond to the protocols $\mathrm{C}, \mathrm{D}, \mathrm{E}$ and $\mathrm{K}$. 
QIAamp DNA Mini Kit produced only a low quantity of high molecular weight DNA (lane K: Fig. 2).

The shorter the storage time was in ethanol, the higher was the molecular weight of the yielded DNA (Fig. 3). Ethanol stored samples at room temperature produced a mix of high and low molecular weight DNA, but degradation decreased as the ethanol concentration increased: 70, 80 and 95\% (lanes G, I and J, respectively: Fig. 3).

No DNA was detected for 4.5 years conserved samples (lanes F and F': Fig. 3). Individual stored in $70 \%$ ethanol at $-20^{\circ} \mathrm{C}$ yielded no detectable DNA (lane H: Fig. 3).
PCR to amplify CO1 gene worked well for the protocols that provided high molecular weight DNA (C, D, E and K), a mix of high and low molecular weight DNA (A, B, I, and J), or low molecular weight DNA (G), indicating the absence of impurities at significant quantities. Samples from protocols $\mathrm{F}$ ' and $\mathrm{H}$, which provided nondetectable DNA on agarose gel, showed a slight amplified fragment (Fig. 4). CO1 gene failed to amplify for protocols A', B' and F.

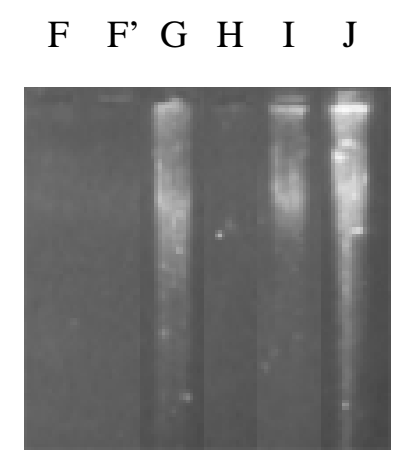

Figure 3 - Electrophoresis in $0.8 \%$ agarose gel of extracted DNA samples. Letters correspond to the protocols F, F', G, H, I and J

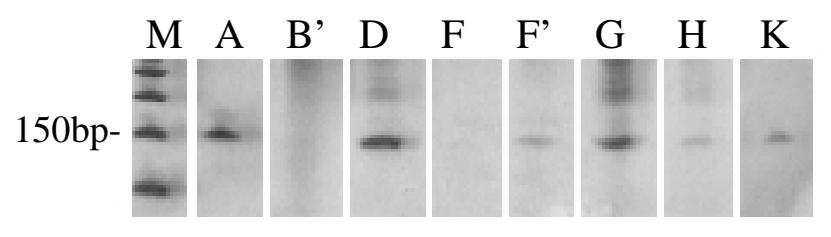

Figure 4 - CO1 amplification of some samples, electrophoresed on 6\% Polyacrylamide gel. M (Molecular Weight marker); protocols A; B'; D; F; F'; G; H and K

\section{DISCUSSION}

Standardizing a DNA extraction protocol is a laborious procedure that comprises changes in several parameters followed by many tests, in order to evaluate specific points that could be damaging DNA samples.
The first attempt - protocol A - provided large amount of degraded DNA. Apparently enzymatic complexes in the hepatopancreas could be the cause of the damage brought out protocol B. It was clear that hepatopancreas did not influence on the DNA quality, but the quantity (according protocol $B$ results). It was also clear that DNA produced by 
extraction from Aegla's hepatopancreas provided a small amount of material, hence this tissue can be discarded from the DNA extraction protocol.

In relation to the conservation method, frozen fresh individuals $30 \mathrm{~min}$ before dissection appeared to be better approach than keeping the specimens iced or in ethanol for a long time. However, this approach requires successive collecting and aquariums, with all theirs supplies, to maintain fresh animals. An alternative way was to keep specimens in ethanol, but the DNA produced had lower molecular weight than that obtained from the animals kept frozen. However, if Aegla's specimens were stored in $95 \%$ ethanol for few days at room temperature, it was possible to obtain a high amount of DNA of high molecular weight as well as degraded DNA (see protocol J: Fig. 3). In this case, the higher was the alcohol concentration, the higher the DNA molecular weight (protocols G, I and J: Fig. 3).

It was not advisable to freeze the ethanol-stored individuals (protocol $\mathrm{H}$ ), because it yielded a minimum amount of DNA and presented a faint fragment amplified by PCR (Fig. 4). Generally, ethanol-stored Aegla at room temperature release its pigments into the alcohol. The iced ethanolstored Aegla did not stain alcohol, but it accumulated pigments in its own tissues, mainly muscles, which co-precipitated with DNA.

Carcinology laboratories generally keep specimens in $70 \%$ ethanol in their collections. The attempts of DNA extraction from 4.5 years ethanol-stored Aegla were unfruitful, except with the addition of $\beta$-mercaptoethanol to the lysis buffer (Protocol F). The $\beta$-mercaptoethanol is a reducing agent that prevents oxidative damage of nucleic acids (Herzer, 2001). This approach resulted in nondetectable quantity of DNA on agarose gel; nevertheless it was enough for the CO1 gene amplification by PCR (Fig. 4). Probably the final ethanol concentration decreased with the accumulated water on the animal body. It would be an interesting datum to test the same conservation time with 80 and $95 \%$ ethanol-stored samples, in order to verify whether the increase of ethanol concentration allowed DNA extraction of better quality. Freezing individuals was another alternative to maintain Aegla specimens. However, if the storage time was upper to one month, the use of $\beta$-mercaptoethanol in lysis buffer was indispensable to warrant an extracted DNA of quality.
Traditional phenol-chloroform method for DNA extraction produced larger quantity of material than QIAmp DNA Mini Kit. Although phenolchloroform method was time consuming and labor intensive, it was more effective in extracting DNA from A. longirostri than the QIAamp DNA Mini Kit. DNA produced by the QIAmp Mini Kit was little, regarding low available tissues for DNA extraction in small invertebrates such as Aeglidae. In spite of this, the produced sample was high molecular weight DNA. Hence, QIAamp DNA Mini Kit could be advisable for molecular techniques that required such quality of nucleic acid.

Only three protocols (A', B' and F) did not produce DNA of good quality for downstream applications, as demonstrated by the $\mathrm{CO} 1$ gene amplification. Even among protocols that provided degraded or non-detectable DNA, the CO1 gene amplification presented positive results. PCR applications require little quantity of DNA and even low molecular weight samples allows amplification, since no contaminations are present. However, methodologies like Southern blots need large quantities of DNA and the sample must not be degraded. Hence, for further applications after DNA extraction, the main points to take into consideration are the quantity and quality of sample that the technique to be used demands, in order to choose a better-adjusted protocol. The best protocol for obtaining DNA of good quality and in a suitable quantity for several downstream applications should, therefore, utilize fresh specimens, with addition of $\beta$-mercaptoethanol to the lysis buffer.

This study presented the procedures that should be adopted in order to get a DNA of good quality for the molecular searches with A. longirostri, and possibly for other Anomura. A suitable protocol was described for DNA extraction from the fresh animals. However, a study about the isolation of a larger DNA quantity from Aeglidae preserved in ethanol for a long time could be elaborated, allowing the utilization of collection specimens, for purposes other than PCR, which required large quantity of samples. Other preservation methods, such as DMSO (dimethyl sulfoxide) $/ \mathrm{NaCl}$ could also be tested. 


\section{RESUMO}

Marcadores moleculares são ferramentas úteis para esclarecer dúvidas a respeito dos Aeglidae, único grupo de crustáceos Anomura de água doce. Essas técnicas dependem da obtenção de DNA de boa qualidade e sem contaminantes. O objetivo deste estudo foi comparar algumas metodologias de extração de DNA de Aegla longirostri. Quatorze protocolos foram analisados, baseados na metodologia tradicional de extração de DNA com fenol-clorofórmio, exceto o protocolo K no qual se utilizou um Kit. Os procedimentos diferiram quanto aos tecidos utilizados e a adição de $\beta$ mercaptoetanol ao tampão de lise. Avaliaram-se também diferentes tempos e maneiras de conservação. Indivíduos congelados apresentaram maior degradação do material obtido conforme o tempo em que ficaram congelados. Para os indivíduos conservados em álcool, aqueles mantidos em etanol $95 \%$ forneceram material de melhor qualidade. A utilização do Mini Kit resultou em uma quantidade muito pequena de DNA de alto peso molecular. O melhor protocolo para extração de DNA de Aeglidae utilizou músculos e brânquias, de indivíduos frescos com adição de $\beta$-mercaptoetanol ao tampão de lise.

\section{REFERENCES}

Bond-Buckup, G. (2003), Família Aeglidae. p. 21-116 In-Manual de Identificação dos Crustacea Decapoda de água doce do Brasil, ed G. A. S. Melo. Loyola, São Paulo, pp 35-112.

Bond-Buckup, G. and Buckup L. (1994), A Família Aeglidae (Crustacea, Decapoda, Anomura). Arq Zool., 32, 159-347.

Chu K. H.; Tong J. and Chan T. (1999), Mitochondrial cytochrome oxidase I sequence divergence in some Chinese species of Charybdis (Crustacea: Decapoda: Portunidae). Biochem Syst Ecol., 27, 461-468.

D'Amato M. E. and Corach D. (1997), Highly repetitive DNA sequences unique to Aeglidae (Anomura). J Crustacean Biol., 17(1), 184-191.

Fratini S. and Vannini M. (2002), Genetic differentiation in the mud crab Scylla serrata (Decapoda: Portunidae) within the Indian Ocean. $J$ Exp Mar Biol Ecol., 272, 103-116.
Herzer S. (2001), DNA purification. In- Molecular Biology problem solver: A laboratory Guide, ed. A. S. Gerstein. Wiley-Liss, New York, pp. 167-196.

Levinton J., Sturmbauer C. and Christy J. (1996), Molecular data and biogeography: resolution of a controversy over evolutionary history of a pantropical group of invertebrates. J Exp Mar Biol Ecol., 203, 117-131.

Moreira A. A. N. and Lima G. R. (1977), Geografia do Brasil, Região Sul. Vol 5. Fundação IBGE, Rio de Janeiro.

Ovenden J. R., Brasher D. J and White R. W. G. (1992), Mitochondrial analyses of the red rock lobster Jasus edwardsii supports an apparent absence of population subdivision throughout Australasia. Mar Biol., 112, 319-326.

Perez-Lozada M.; Jara C.; Bond-Buckup, G and Crandall, K. A. (2002a), Phylogenetic relationships among the species of Aegla (Anomura: Aeglidae) freshwater crabs from Chile. J Crustacean Biol., 22(2), 304-313.

Perez-Lozada M.; Jara C.; Bond-Buckup, G and Crandall, K. A. (2002b), Conservation phylogenetics of Chilean freshwater crabs Aegla (Anomura, Aeglidae): assigning priorities for aquatic habitat protection. Biol Conserv., 105, 345-353.

Sambrook J. and Russell D. W. (2001), Molecular cloning: a laboratory manual. 3rd edition. Cold Spring Harbor Laboratory Press, New York.

Schubart C. D., Cuesta J. A., Diesel R. and Felder D. L. (2000), Molecular Phylogeny, Taxonomy and Evolution of Nonmarine Lineages within the American Grapsoid crabs (Crustacea: Brachyura). Mol Phylogenet Evol., 15(2), 179-190.

Staton J. L. and Felder D. L. (1995), Genetic variation in populations of ghost shrimp genus Callichirus (Crustacea: Decapoda: Thalassinoidea) in the western Atlantic and Gulf of Mexico. 1995. Bull Mar Sci., 56(2), 523-536.

Xu Z., Primavera J. H., de la Pena L. D., Pettit P., Belak J. and Alcivar-Warren A. (2001), Genetic diversity of wild and cultured Black Tiger Shrimp (Penaeus monodon) in the Philippines using microsatellites. Aquaculture, 199: 13-40. 